\title{
Undergraduates' awareness, utilization and satisfaction with online public access catalogue (OPAC) in public university libraries in Nasarawa State, Nigeria
}

\author{
David T. Aju, $P h D$ \\ Senior Lecturer \\ Department of Library and Information Science \\ Benue State University, Makurdi \\ E-mail: ajudave@yahoo.com \\ Cell: +2348135383344 \\ Simon Ternenge Tofi, CLN \\ Librarian II \\ Benue State School of Nursing, Makurdi \\ E-mail: ternengetofi@gmail.com \\ Cell: +2347036431885
}

\begin{abstract}
The study investigated undergraduate's awareness, utilization and satisfaction with online public access catalogue (OPAC) in selected University libraries in Nasarawa State, Nigeria. Four (4) objectives with corresponding research questions guided the study. The study adopted survey research design. The population of the study was 7,233 registered library users (undergraduates) in two (2) public universities in Nasarawa State, namely Federal University Lafia (FULAFIA) and Nasarawa State University, Keffi (NSUK). The sample size for the study was 379 drawn using Taro-Yemene's formula for sample size determination. Proportionate stratified random sampling technique was used to select the sample of respondents from the two (2) universities under study (i.e.) FULAFIA with 150 and NSUK, 299 respectively. Questionnaire was used as instrument for data collection. A total of 379 questionnaire were distributed and 362 retrieved for analysis representing a percentage of $95.5 \%$. Data was analyzed using frequency counts; mean scores and standard deviation. Findings of the study revealed that, undergraduates were highly aware of Online Public Access Catalogue in selected University Libraries in Nasarawa State. The finding also revealed, undergraduates in selected university libraries in Nasarawa State utilized OPAC to a little extent and students were not satisfied with the use of OPAC, hence their extent of satisfaction derived from the use of OPAC was little extent. Findings further revealed factors affecting use of OPAC by undergraduates in selected university libraries to include: library guide to explain how to use the OPAC is not available, unstable power supply, library staff not friendly, network/server problems, lack of computer systems, among others. Finally, conclusion and recommendations were made based on the findings of the study.
\end{abstract}

Keywords: Awareness, Utilization, Satisfaction, OPAC, Undergraduates, Public university libraries, Nassarawa State, Nigeria

\section{Introduction}

Globally, university libraries have vital role in the development and promotion of university education such is the case in Nasarawa State in Nigeria. A university library is a library that serves the information needs of the university community through provision of information resources that supports teaching, learning, research, community service etc. In order to provide a conducive atmosphere for research, the university library provides current research materials and trained personnel to organize available information materials, assist faculties and students in accessing, retrieval and use of these resources 
David T. Aju and Simon Ternenge Tofi: Undergraduates awareness, utilization and satisfaction with online public access catalogue (OPAC) in public university libraries in Nasarawa State, Nigeria

(Onuoha, Umahi \& Bamidele, 2013). According to Raul, Belapurkar and Munnolli (2016), university libraries are information gateways of the universities; they transform the acquired information resources in an organized manner with searchable options which connects the past and future. The authors further stated that, university libraries are brain centre of their institutions, as they acquire and stock new ideas.

Information resources acquired by libraries are useless when access is not provided. The library catalogue is a fundamental tool used in accessing library resources. According to Adedibu, Akinboro and Abdulsalam (2012), there is strong need to organize the library collections for easy access by users, if the collections are not organized, the collections becomes useless. One acceptable means of organizing library collections is described by librarians as cataloguing. Thus, cataloguing is an essential process that provides access to all acquired information resources of the library for professional growth and development. Catalogue as a retrieval tool that provides access point to resources in a way that users will be able to find the needed material and information. Without proper cataloguing of library resources, users will not be aware of the resources, use and be satisfied. The resultant effect is users frustration.

University libraries in Nasarawa State invest huge amount every year on selection, acquisition, processing, and storage of information resources to serve its users. All these efforts are useless, if these resources remain unused or failed to serve the needs of the users. In this regard, factors such as lack of awareness of the resources, and access often create problems on the part of the users to use the library resources effectively. The introduction of computer technology in university libraries have changed the entire environment (Gohain \& Saikia, 2013). According to the authors, it has brought changes in access and retrieval of information resources. In support of this, Tyonum (2015) stated that computers in libraries aid in the production and maintenance of catalogues. This is because some cataloguing formats are now available.

In order to create awareness of the available resources and ensure their use by the target users, university libraries under study offers new technology base services. Onuoha, Umahi andBamidele, (2013) affirms that, as a means of ensuring that information materials are available and accessible, university libraries are providing modern catalogues to display what they have. Recently, most university libraries in Nigeria have joined their counterparts in advanced countries in the use of computers for processing library collections (Adedibu et al, 2012). Today, a few number of university libraries in Nigeria have automated their technical operations and services. Online public access catalogue(OPAC) is one of these means that facilitate access to information in university libraries. According to Aina cited in Kumar (2017), the use of computerized catalogue has made processing of library collections more accurate, interesting and faster.

An OPAC is an online database retrieval tool held by a library or group of libraries. According to Narayanaswamy (2019), the OPAC is an information retrieval tool considered by short bibliographic records, mainly books, journals, audio-visual and non-book materials available in a library. The author further stated that, OPAC is helpful to university library users to access and locate the library resources efficiently and effectively. Aina cited by Onuoha, Umahi and Bamidele (2013) also, stated that 
David T. Aju and Simon Ternenge Tofi: Undergraduates awareness, utilization and satisfaction with online public access catalogue (OPAC) in public university libraries in Nasarawa State, Nigeria

OPAC is the most modern form of library catalogue, whereby bibliographic records of all the documents in a collection are stored in the computer memory disk. It is a tool designed to facilitate information retrieval process in this new age. OPAC provides great flexibility and numerous options to users to access information pertaining to library resources by combining two or more bibliographic fields or access point (Kumar \& Vohra, 2013).

Preliminary observation by the researchers revealed that awareness and utilization of OPAC seems to be a challenge of undergraduates in universities in Nigeria. Research by Ebiwolate (2010) revealed that a majority of undergraduates were not aware of libraryOPAC and its uses. Similarly, Onuoha, Umahi andBamidele (2013) reported poor OPAC utilization among the final year students. Also, Bamidele et al, (2014) revealed that majority of the library users were not aware that OPAC could be used to facilitate retrieval of library information resources, only (26\%) of the users used OPAC independently to retrieve library information resources. Likewise, Adedibu (2008) in his work reported that the users of OPAC represented a small portion in university libraries.

Awareness and utilization of OPAC seems to be challenging among undergraduates in university libraries due to a myriad of factors. These factors hinder the students to effectively and efficiently access and utilize certain information resources in the library. some of the factors affecting undergraduates use of online public access catalogue as reported by Ogbole and Atinmo (2017) include: lack of personnel with ICT skills in libraries, user education, maintenance, inadequate training on how to use ICT resources, erratic power supply, testing of OPAC in libraries, lack of funds to support
OPAC project in libraries, poor OPAC awareness creation by library personnel, inadequate library space, ICT skills possessed by undergraduates, difficult OPAC interface design, searching capabilities of OPAC by undergraduate students and also, user convenience/satisfaction with OPAC use. Similarly, Gana, Ajibili and Dare (2019) revealed slow connectivity of networks, inadequate searching, and limited access to computers as factors affecting the use of OPAC by the patrons. Ansari and Amita (2008), stated that OPAC provides users with online access to the library's catalogue by allowing them to search and retrieve records from the online catalogue and depending on the underlying library management software.

From the foregoing, it is clear that utilization of OPAC in university libraries is very important to users. This is why university libraries in Nigeria and particularly those in Nasarawa State have subscribed to its use to effectively deliver services to her library patrons (undergraduates). While this is a welcome development, it is important to occasionally assess the effectiveness of the OPAC especially from user's point of view. This is necessary considering the uniqueness of each university library and the fact that periodic assessment will provide realistic picture of OPAC performance aiding managerial decisions on issues affecting the library catalogue. It is in the light of this, that the researchers investigates awareness, utilization and satisfaction with online public access catalogue among undergraduates in selected university libraries in Nasarawa State, Nigeria.

\section{Objectives of the study}

The main objective of this study was to investigate undergraduatesawareness, utilization and satisfaction with OPAC in 
David T. Aju and Simon Ternenge Tofi: Undergraduates awareness, utilization and satisfaction with online public access catalogue (OPAC) in public university libraries in Nasarawa State, Nigeria

public university libraries in Nasarawa State, Nigeria. Specifically, the study sought to:

1. ascertain undergraduates' level of awareness of OPAC in public university libraries in Nasarawa State;

2. determine the extent of utilization of OPAC by the undergraduates;

3. investigate the extent of satisfaction derived from the utilization of OPAC by the undergraduates; and

4. determine the factors affecting use of OPAC by the undergraduates.

\section{Research questions}

This study answered the following research questions:

1. What is the level of awareness of the undergraduates of OPAC in public university libraries in Nasarawa State, Nigeria?

2. What is the extent of utilization of OPAC the undergraduates?

3. What is the extent of satisfaction derived from the utilization of OPAC by the undergraduates?

4. What are the factors affecting use of OPAC by the undergraduates?

\section{Literature Review}

Awareness is defined as an understanding of the activities of others which provides a context for your own activity (Ezema, 2015). According to Uche and UdoAnyanwu (2019), awareness refers to the consciousness of some knowledge about a situation or fact. Similarly, Hornsby (2015) defined awareness as the fact of knowing that something exist. It simply means knowing something, it is an essential factors that determines use. In this context, awareness of online public access catalogue means having knowledge or idea of the online public access catalogue that is available in the library for use by undergraduate students to facilitate easy accessibility and retrieval of needed information resources for learning and research. Awareness of OPAC means having knowledge of OPAC, understanding how OPAC works, appreciation of its value by undergraduates in university libraries. Gohain and Saikia (2013) reported that students were aware that OPAC help users to locate documents by author, title or by subject on the shelves. Similarly, Thanuskodi (2012) found that a majority of users consulted OPAC to know the availability and location of the requisite documents. For OPAC to be effectively used by undergraduate students, they have to be aware of its existence through various awareness programmes in the library. Awareness programmes put in place in university libraries to create awareness of the existence of OPAC include; Current Awareness Services (CAS), exhibitions, and display of list of new arrivals, pasting of posters and pictures on notice board for users to peruse, etc.

Utilization of a resource is the act of exploiting a resource to satisfy an information need. Effective utilization of Online Public Access Catalogue by undergraduate students in university libraries in Nigeria and particularly, in Nasarawa state enhances knowledge and quality of research output. Uhegbu (2007) defined utilization as the appropriate use of acquired information. According to the author, utilization of resources means taking full advantage of available resources. Utilization of OPAC by library users depends largely on the extent to which they are aware of its availability and impact of use (Gana, Ajibili \& Dare, 2019). The extent of utilization also determines the quantity and quality of information obtained and consequently, research output. Uhegbu (2007) asserted that utilization has to do with putting into 
David T. Aju and Simon Ternenge Tofi: Undergraduates awareness, utilization and satisfaction with online public access catalogue (OPAC) in public university libraries in Nasarawa State, Nigeria

appropriate use of acquired information. One would therefore define OPAC utilization as actual putting into appropriate use the OPAC of the university libraries in the study area.

Effective use of OPAC has made the library collections easily accessible to everyone by breaking the physical boundaries of the library. A research conducted on use of OPAC at Annamali university library by Thanuskodi (2012) reported that only one-third of the users utilized OPAC frequently. Similarly, Gahain and Saikia (2013) also reported that majority of the users never utilized OPAC in Tezpur university library. The authors further revealed that, students prefer to browse through the shelves to find or locate books because there is limited training program for library users in the university to properly use the library OPAC. Therefore, the authors proposed user training program for the use of OPAC.

According to Hornby (2015) satisfaction is good feeling one has when one has achieved something or when something that one wanted happened; something that gives you a good feeling. Therefore, user's satisfaction is result of outcome of use of a computer application. In this context, satisfaction is the extent of good feeling of undergraduates in university libraries when they take advantage of the online OPAC as the computer technology available in the library that meets their information requirements or needs. It implies the level of acceptability of the operation of OPAC by undergraduate students in universities. Narayanaswamy (2019) opined that OPAC is designed to satisfy a wide range of users. For example, users who have little knowledge of OPAC to librarians who are experienced in online database searching. The author further reported that, library users were satisfied with the university
OPAC facility, and very few users were neither satisfied nor dissatisfied. In the same vein, Onuoha, Umahi and Bamidele (2013) revealed that students were moderately satisfied with the operations of OPAC to a large extent. Research conducted by Sankari, Chinnasamy, Balasubramanian and Muthuraj (2013) reported that out of 151 users a very few i.e. $2(1.3 \%)$ were fully satisfied with OPAC use in Unnamalai Institute of technology in Kovilpatti (Tamil Nadu), one-fourth were satisfied a little, one-third moderately satisfied with OPAC use.

An undergraduate is a university student who has not yet received a first degree. Undergraduate, according to Cambridge dictionary online (2019), is a student who is studying for his/her first degree at college or university. In other ways, undergraduate is one who have not yet bagged a bachelor's degree. In context of this study, undergraduates are students who are currently undertaken first degree programmes in universities in Nasarawa State.

Undergraduates use of OPAC depends on how well university libraries provide internet facilities such as computers, bandwidth, databases, as well as awareness of ICT facilities to meet their information needs. Shorunke, Eluwole and Gbenu (n.d.) reported that undergraduates visits to university libraries and information centers for research are frustrated due to lack of awareness of OPAC operation, inadequate computers/internet facilities, and other basic ICT skills to access, retrieve and exploit information materials.

\section{Methods}

The descriptive survey research design was adopted for this study. The geographical coverage for the study was Nasarawa State in North Central Nigeria. The study covers the only two (2) public 
David T. Aju and Simon Ternenge Tofi: Undergraduates awareness, utilization and satisfaction with online public access catalogue (OPAC) in public university libraries in Nasarawa State, Nigeria

universities namely, Federal University Lafia (FULAFIA), and Nasarawa State University, Keffi (NSUK), Nasarawa State. The population for the study was 7,233 registered library users (undergraduates) from the two universities. FULAFIA with population of 2,871 and NSUK with 4,362 (Source: data obtained from office of the university librarians in the two universities under study, 2020). The sample size for the study comprised379 undergraduates drawn using Taro-Yamene's formula for sample size determination. Proportionate stratified random sampling technique was used to select the sample of respondents from the two (2) universities (i.e. FULAFIA with
150 and NSUK, 229) making a total of 379. Data for the study was analyzed using descriptive statistics of frequency count, mean scores and standard deviation. The mean bench mark is 2.50 . Therefore, any item with a mean value of 2.50 and above is accepted/agreed while 2.49 and below is rejected/disagreed.

\section{Results}

The result of the study are presented according to the research questions.

Research question one: What is the level of awareness of the undergraduates of OPAC in public university libraries in Nasarawa State, Nigeria?

Table 1: Mean and standard deviation of level of awareness of the undergraduates of OPAC in public university libraries in Nasarawa State, Nigeria

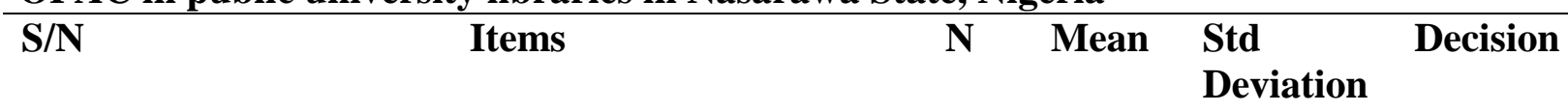

1 Are you aware that most of the materials $\begin{array}{lll}362 & 3.54 & 0.99\end{array}$

Highly Aware available in your university library can be accessed outside the library building using OPAC?

2 Are you aware of the existence of OPAC in your university library?

3 Are you also aware that OPAC is a device to locate print and non-print materials?

4 What is your level of awareness of OPAC in your university library?

5 Are you aware that you can link with other online databases via your university library OPAC?

6 Are you also aware that your university library subscribes to over 20 electronic databases that you can navigate using the OPAC interface?

7 Are you aware that it is faster to retrieve information on any objective via OPAC of your university library?

Table 1 shows the level of awareness of the undergraduates of OPAC in public university libraries in Nasarawa State. Result of the study indicates that all the items have mean scores above the bench mark of 2.50. The mean scores range from 2.97 to 3.54 . The standard deviation of the respondents ranged from 0.99 to 1.28 .

The finding on research question one in Table 1 revealsthat the 
David T. Aju and Simon Ternenge Tofi: Undergraduates awareness, utilization and satisfaction with online public access catalogue (OPAC) in public university libraries in Nasarawa State, Nigeria

undergraduates were highly aware of OPAC. This finding is in agreement with that of Gohain and Saikia (2013) who reported that students in their study were aware of OPAC to a high extent. Findings of the study disagree with that of Makun, Danjuma and Dare (2019) who reported that most of the students were aware of the OPAC to a very little extent, and some were not aware of the OPAC services at all, hence they preferred to physically browse through the library shelves. The probable reason for the result in Table 1 could be fact that the university libraries mounted programmes to create awareness of the existence and use of OPAC.

Research question two: What is the extent of utilization of OPAC by the undergraduates?

Table 2: Mean and standard deviation on the extent of utilization of OPAC by the undergraduates

\begin{tabular}{|c|c|c|c|c|c|}
\hline $\mathbf{S} / \mathbf{N}$ & Items & $\mathbf{N}$ & Mean & $\begin{array}{l}\text { Std } \\
\text { Deviation }\end{array}$ & Decision \\
\hline 1 & $\begin{array}{l}\text { I use OPAC to know the bibliographical } \\
\text { details of title/documents }\end{array}$ & 362 & 2.98 & 1.10 & Great Extent \\
\hline 2 & $\begin{array}{l}\text { I use OPAC to locate documents on the } \\
\text { shelves }\end{array}$ & 362 & 3.02 & 0.93 & Great Extent \\
\hline 3 & $\begin{array}{l}\text { OPAC assist me to know whether a } \\
\text { particular book is on the shelf or not }\end{array}$ & 362 & 3.27 & 0.95 & Great Extent \\
\hline 4 & $\begin{array}{l}\text { I use OPAC to know what a library have } \\
\text { on a given author, title and subject in the } \\
\text { university library. }\end{array}$ & 362 & 3.19 & 0.93 & Great Extent \\
\hline 5 & $\begin{array}{l}\text { It is very rewarding to use OPAC to } \\
\text { ascertain a document without visiting } \\
\text { library }\end{array}$ & 362 & 2.34 & 1.20 & Little Extent \\
\hline 6 & $\begin{array}{l}\text { I use OPAC to search different type of } \\
\text { documents }\end{array}$ & 362 & 2.45 & 1.07 & Little Extent \\
\hline 7 & $\begin{array}{l}\text { I use OPAC to know the status of a } \\
\text { document }\end{array}$ & 362 & 2.41 & 1.27 & Little Extent \\
\hline 8 & $\begin{array}{l}\text { I use OPAC to know the latest additional } \\
\text { list of books in the library }\end{array}$ & 362 & 2.37 & 1.20 & Little Extent \\
\hline 9 & $\begin{array}{l}\text { I use OPAC to know about the availability } \\
\text { of journals in the library }\end{array}$ & 362 & 2.15 & 0.65 & Little Extent \\
\hline 10 & I use OPAC to complete my term papers & 362 & 2.13 & 0.83 & Little Extent \\
\hline
\end{tabular}

Table 2 shows the extent of utilization of OPAC by undergraduates in the public university libraries. Result showed that, items, 1,2,3 and 4 with mean scores range from $2.98,3.02,3.27$, and 3.19 are above the benchmark of 2.50 indicating great extent. While items $5,6,7,8,9$ and 10 with mean scores of $2.34,3.45,2.41,2.37,2.15$ and 2.13 are below the cut-off mark of 2.50, which indicate little extent.
The finding on research question 2 in Table 2 shows that the respondents utilized OPAC to a little extent. This agrees with Thanuskodi (2012) who reported that only one-third of the users utilized OPAC frequently. The result is also in consonance with that of Gohain and Saikia (2013) who discovered that a majority of the users (students) never utilized OPAC in Tezpur University 
David T. Aju and Simon Ternenge Tofi: Undergraduates awareness, utilization and satisfaction with online public access catalogue (OPAC) in public university libraries in Nasarawa State, Nigeria

Library. The reason could be attributed to low level of ICT skills among some of the students.
Research question three: What is the extent of satisfaction derived from the utilization of OPAC by the undergraduates?

Table 3: Mean and standard deviation on the extent of satisfaction derived from the utilization of OPAC by the undergraduates

\begin{tabular}{|c|c|c|c|c|c|}
\hline $\mathbf{S} / \mathbf{N}$ & Items & $\mathbf{N}$ & Mean & Std. & Decision \\
\hline 1 & $\begin{array}{l}\text { When I use OPAC, I know the } \\
\text { bibliographical details of title/documents }\end{array}$ & 362 & 3.42 & 0.77 & Great Extent \\
\hline 2 & $\begin{array}{l}\text { I use OPAC to locate documents on shelve } \\
\text { and I enjoyed it }\end{array}$ & 362 & 3.27 & 0.96 & Great Extent \\
\hline 3 & $\begin{array}{l}\text { I use OPAC to know whether a particular } \\
\text { book is on the shelf or not }\end{array}$ & 362 & 3.21 & 1.01 & Great Extent \\
\hline 4 & $\begin{array}{l}\text { I use OPAC to know what the library have } \\
\text { on a given author, title, and subject without } \\
\text { wasting time }\end{array}$ & 362 & 3.15 & 1.22 & Great Extent \\
\hline 5 & $\begin{array}{l}\text { Using OPAC, I know about a document } \\
\text { without visiting the university library }\end{array}$ & 362 & 2.33 & 1.11 & Little Extent \\
\hline 6 & $\begin{array}{l}\text { Using OPAC, I search different types of } \\
\text { document without frustration }\end{array}$ & 362 & 2.15 & 0.95 & Little Extent \\
\hline 7 & $\begin{array}{l}\text { OPAC enables one to know the status of a } \\
\text { document to complete an assignment }\end{array}$ & 362 & 2.30 & 0.98 & Little Extent \\
\hline 8 & $\begin{array}{l}\text { When student use OPAC list of new } \\
\text { arrivals is known }\end{array}$ & 362 & 2.21 & 0.66 & Little Extent \\
\hline 9 & $\begin{array}{l}\text { Using OPAC of libraries enables one } \\
\text { complete his term paper on time }\end{array}$ & 362 & 2.24 & 1.27 & Little Extent \\
\hline 10 & $\begin{array}{l}\text { My academic performance have improved } \\
\text { because I use OPAC all the time }\end{array}$ & 362 & 1.95 & 0.51 & Little Extent \\
\hline
\end{tabular}

Table 3 reveals extent of satisfaction derived from the utilization of OPAC by the undergraduates. Items $1,2,3$, and 4 with mean values ranging from $3.42,3.27,3.21$, 3.15 above the cut-off mark of 2.50 indicating great extent while items $5,6,7,8,9$ and 10 with mean values of 2.33 , $2.15,2.30,2.21,2.24$ and 1.95 are below the cut-off mark of 2.50. Hence, the respondents indicated little extent of satisfaction from the utilization of OPAC.

The result on research question three in Table 3 indicates that the satisfaction derived from utilization of OPAC by undergraduates used in this study was to a little extent (i.e.) students were not satisfied with the use of the OPAC. This findings corroborates that of Sankari, Chinnasamy, Balasubramanian and Muthuraj (2013) who observed that very few library users $(1.3 \%)$ were fully satisfied with OPAC use, one-fourth were satisfied a little, while one-third were moderately satisfied with OPAC use. The result of the study not agree with that of Onuoha, Umahi and Bamidele (2013) who discovered that students were moderately satisfied with the operations of OPAC.

Research question four: What are the factors affecting use of OPAC by the undergraduates? 
David T. Aju and Simon Ternenge Tofi: Undergraduates awareness, utilization and satisfaction with online public access catalogue (OPAC) in public university libraries in Nasarawa State, Nigeria

Table 4: Mean and standard deviation on the factors affecting use of OPAC by the undergraduates

\begin{tabular}{|c|c|c|c|c|c|}
\hline $\mathbf{S} / \mathbf{N}$ & Items & $\mathbf{N}$ & Mean & Stddeviation & Decision \\
\hline 1 & $\begin{array}{l}\text { Library guide to explain how to use the } \\
\text { OPAC is not available }\end{array}$ & 362 & 3.06 & 1.12 & Agreed \\
\hline 2 & Lack of awareness programmes & 362 & 2.22 & 0.91 & Disagreed \\
\hline 3 & Unstable power supply & 362 & 3.46 & 0.87 & Agreed \\
\hline 4 & Library staff not friendly & 362 & 3.47 & 0.73 & Agreed \\
\hline 5 & Network/server problem & 362 & 3.67 & 0.74 & Agreed \\
\hline 6 & Lack of computer system & 362 & 3.68 & 0.66 & Agreed \\
\hline 7 & $\begin{array}{l}\text { Book(s) not found on shelves indicated } \\
\text { by OPAC }\end{array}$ & 362 & 1.69 & 0.18 & Disagreed \\
\hline 8 & $\begin{array}{l}\text { Lack of basic ICT skills to search and } \\
\text { use OPAC }\end{array}$ & 362 & 3.90 & 0.54 & Agreed \\
\hline 9 & OPAC access is password protected & 362 & 3.88 & 0.56 & Agreed \\
\hline 10 & $\begin{array}{l}\text { Lack of orientation of students on the } \\
\text { part of library management }\end{array}$ & 362 & 1.81 & 0.56 & Disagreed \\
\hline 11 & OPAC interface is not user friendly & 362 & 3.72 & 0.45 & Agreed \\
\hline 12 & $\begin{array}{l}\text { Lack of knowledge of the OPAC URL } \\
\text { address }\end{array}$ & 362 & 1.51 & 0.43 & Disagreed \\
\hline
\end{tabular}

Table 4 reveals factors affecting use of OPAC by the undergraduates. The table shows that items $1,3,4,5,6,8,9$, and 11 have mean values ranging from 3.06 to 3.90 criterion mean(2.50). Thus these items were indicated as factors affecting use of OPAC in the university libraries. While items 2, 7, 10 and 12 with mean values ranging from $1.51,1.69,1.81$, and 2.22 were below 2.50 which is disagree.

The finding on research question 4 in Table 4 reveals factors affecting use of online public access catalogue by the undergraduates of the public university libraries in NasarawaState to include: library guide to explain how to use the OPAC is not available, unstable power supply, library staff not friendly, network/server problems, lack of computer systems, lack of basic ICT skills to search and use OPAC, OPAC access is password protected, as well as OPAC interface is not user friendly. This is in line with Kumar (2017) who reported difficulties in locating documents, network/server problems, lack of proper guideline as well as unstable power supply as problems faced by his respondents with use OPAC. This result also corroborates that of Makun, Danjuma and Dare (2019) who found that slow connectivity and inadequate searching skills were the problems faced by his research subjects while using the OPAC services. The finding also corroborates that of Ogbole and Atinmo(2017) who discovered that erratic power supply, inadequate training on how to use ICT resources, and lack of funds to support OPAC project in libraries as factors affecting OPAC sustainability use in libraries.

\section{Conclusion}

The study has revealed that the undergraduates used in this study were highly aware of the existence of OPAC in the public university libraries in NasarawaState, Nigeria. Students also utilized OPAC to a little extent and were not satisfied with the use of OPAC in the university libraries. The students however were faced with myriad of factors 
David T. Aju and Simon Ternenge Tofi: Undergraduates awareness, utilization and satisfaction with online public access catalogue (OPAC) in public university libraries in Nasarawa State, Nigeria

affecting use of OPAC which further studies are required without which OPAC and the university libraries may be doing a lot of disservice to users.

Based on the findings of the study, the following recommendations are made:

1. The undergraduates indicated that they utilized OPAC to a little extent. Therefore, the university libraries should provide more awareness programmes to encourage students to use OPAC more.

2. The study revealed that students derived little satisfaction from the use of OPAC, therefore, the paper recommends that the university management should put in place strategies that may encourage students to take advantage of OPAC in their respective libraries in order to derive maximal satisfaction.

3. University management should ensure that stable power supply is provided with appropriate number of computers and servers to enhance use of OPAC in the public university libraries.

\section{References}

Adedibu, L.O. (2008). Catalogue use by science students in the University of Ilorin, Nigeria. International Journal of Library and Information Science, 58(1), 58-62

Aina, L.O. (2014). Library and Information Science Text for Africa. Ibadan: Third World Information Services Limited.

Ansari, M. A., \&Amita (2008). Awarenessand use of OPACs in five DelhiLibraries.Electronic Library, 26(1),111-129.

Asokan, L. \&Dhanavanda, S. (2015). Awareness and usage of Online Public Access Catalogue (OPAC) by students and faculty members:
A case study. Journal of Emerging

Trends in Computing and Information Sciences, 6(4), 227231.

Bamidele, I.A. et al, (2014). Faculty member's awareness and use of online public access catalogue (OPAC) services at Babcock University, Nigeria: A study. Information and Knowledge Management, 4(11), 29-37.

Ebiwolate, P.B. (2010). Use of the library catalogue by undergraduate students in Niger Delta university library.Library Philosophy and practice (e-journal). Retrieved from

http://www.digitalcommons.unl/.ed u/libphilprac/392

Ezema, A.L. (2015). Awareness and access to electronic information resources by students of federal colleges of education in SouthEast, Nigeria. Retrieved from http://www.webpages.uidaho.edu/

Gana, M., Ajibili, D.O., \& Dare, A. (2019). Awareness and use of OPAC by patrons of Bingham University Library, Karu, Nasarawa State, Nigeria. Journal of ICT Development, Applications and Research, 1, 61-69.

Gohain, A. \& Saikia, M. (2013). Use and users satisfaction on online public access catalogue (OPAC) services among B.Tech students of school of Engineering in Tezpur University: A survey. Library Philosophy and Practice (ejournal). Retrieved from http://digitalcommons.un/edu/libph ilprac/990

Hornby, A.S. (2015). Oxford Advanced Learners Dictionary, ( $9^{\text {th }}$ Edition). Oxford University Press.

Kumar, A. (2017). Awareness and use of online public access catalogue 
David T. Aju and Simon Ternenge Tofi: Undergraduates awareness, utilization and satisfaction with online public access catalogue (OPAC) in public university libraries in Nasarawa State, Nigeria

services among the students of Department of English, Mathematics, and Commerce of Kurukshetra Universityu, Kurukshetra, Haryana: India. International Journal of Digital library services, 7(2):51-61

Kumar, S. \& Vohra, R. (2013). Online public access catalogue usage at Panjab University Library, Chandigarh.DESIDOC Journal of Library and Information Technology, 31(4), 302-310.

Makun, G., Danjuma, O.A., \& Dare, A. (2019). Awareness and use of OPAC by patrons of Bingham University Library, Karu, Nasarawa State, Nigeria. Journal of ICT Development, Applications and Research, 1, 61-69

Narayanaswamy, B.V. (2019). Awareness and use of online public catalogue (OPAC) Services by the users of Bangalore University Library: A study. International Journal of Library and Information Studies, 9(2), 63-70.

Ogbole, J.S. \& Atinmo, M. (2017). Factors affecting online public access catalogue provision and sustainable use of undergraduates in two selected university libraries in Ogun and Oyo State, Nigeria. Journal of Research and method in Education,7(4), 14-25.

Onuoha, U.D., Umahi, F.O. \& Bamidele, I.A. (2013). Use and satisfaction with online public access catalogue in selected university libraries in Ogun State, Nigeria. Information and Knowledge Management,3(11), 1-5.

Ruzegea, M. (2012). The usability of OPAC interface features: The perspective of postgraduate students at international Islamic University Malaysia (IIUM).
Library Philosophy and Practice (e-journal). Retrieved fromhttps://digitalcommons.unl.ed $\mathrm{u} /$ cgi/viewcontent.cgi?article $=1765$ $\&$ context=libphilprac.

Sankari; R.L. Chinnasamy, K., Balasubramanian, P, \&Muthuraj, R. (2013).A study on the use of online public access catalogue (OPAC) by students and faculty members of Unnamalai Institute of Technology in Kovilpatti (Tamil Nadu).International Journal of Library and Information Studies, 3(1), 17-26.

Shorunke, A.O., Eluwole, O.A. \& Gbenu, S.A. (n.d). Evaluating users' satisfaction with Landmark University's online public access catalogue. Samuru Journal of Information Studies, 14(1 \& 2): 13 19

Siddagandaiah, K.N. \& Muthuraja, S. (2017). Degree of satisfaction with OPAC: A survey of undergraduate college library. International Journal of Library and Information Studies, 7(1), 218-224

Thanuskodi, S. (2012). Use of online public access catalogue at Annamalai University Library. International Journal of Information Science, 2(6), 70-74. Doi:10.5923/j.ijis.20120206.1

Tyonum, M.N. (2015). Information and Communication Technology (ICT) application in library and information services.In R.E. Ozioko (Ed), Book of readings in library and information science, (pp. 85-103). Makurdi: Climax Graphix and Publishers Limited.

Uche, A.C. \& Udo-Anyanwu, A.J. (2019). Awareness and utilization of social media by tertiary institutions librarians in Abia and Imo state, Nigeria. LibraryPhilosophy and 
David T. Aju and Simon Ternenge Tofi: Undergraduates awareness, utilization and satisfaction with online public access catalogue (OPAC) in public university libraries in Nasarawa State, Nigeria

Practice (e-journal). Retrieved from https://digitalcommons.unl .edu/libphilprac/2307.

Uhegbu, A. N. (2007). The information user: Issues and themes. Okigwe; WHYTEM Publishers Nigeria. 66.

Velmurugan, V.S. \& Amudha, G. (2012). Usage patterns of OPAC among faculty members in India Colleges.
Mass communicator. International Journal of Communication Studies, 6(3):37-40.

Vijayakumar, S. \& Manasa, S. (2018). Attitude of OPAC users at Regional Institute of Education, Mysuru: A survey. International Research: Journal of Library and Information Science, 8(2), 268277. 